\title{
Program Review Group Report
}

National Cancer Institute

\section{Source}

National Cancer Institute. Program Review Group Report. NCI Thesaurus. Code C19474.

Document type: a report from a Program Review Group to the NCI Director. 